\author{
Czestaw Grajewski \\ Uniwersytet Kardynata Stefana Wyszyńskiego w Warszawie
}

\title{
Stowarzyszenie Polskich Muzyków Kościelnych. Retrospektywa
}

Przed twórcami muzyki sakralnej, będącej szczególnym gatunkiem muzyki, Kościół stawia wymagania także szczególne. Oprócz bowiem wysokiego poziomu artystycznego - podobnie jak w przypadku artystowskiej sztuki muzycznej o świeckiej naturze - muzyka liturgiczna musi spełniać dodatkowo kryteria ustanowione dla niej przez Kościól. Jednakże jak dowodzi historia, co pewien czas wskutek niebezpiecznego zbliżenia muzyki kościelnej do świeckiej dochodzi do naruszenia tej delikatnej granicy, w efekcie którego obrońcy czystości stylu kościelnego poczynają usilnie domagać się jego oczyszczenia z elementów świeckich. W takich właśnie przełomowych momentach muzyka sakralna stawała się przedmiotem szczególniejszego zainteresowania papieży, liturgistów i samych muzyków. Owo zanieczyszczenie liturgii elementami świeckimi, jakkolwiek bulwersujące, mimo wszystko nie powinno budzić nadmiernego zdumienia. Wszak muzyka, i w ogólności sztuka, realizowana jest w rzeczywistości ziemskiej, stąd jej podatność na zeświecczenie.

Jak każdy powrót na drogę uzdrowienia, tak i w przypadku muzyki kościelnej jest to proces zarówno długotrwały, jak i bolesny. Dzieje muzyki notują takich prób co najmniej kilka, ale na jedną warto zwrócić baczniejszą uwagę, jako że na ogół nie wiąże się faktu jej zaistnienia na terenach polskich z uwarunkowaniami społeczno-politycznymi.

Myślę o ruchu cecyliańskim, którego nie ma potrzeby teraz przedstawiać. Jak wiadomo, prąd ten dotarł do Polski w schyłkowym okresie pozytywizmu, a więc stosunkowo szybko. Warto przy tym zauważyć, że na naczelne hasło polskiego pozytywizmu, „praca u podstaw”, można spojrzeć jak na postulat, który - świadomie czy nie - próbowano realizować na gruncie także kościelnym poprzez między innymi podniesienie poziomu muzyki liturgicznej oraz poprawę sytuacji materialnej muzyków. Praca pozytywistów była pracą natury głównie oświatowej. Podobnie więc jak oni rozumieli konieczność pracy na rzecz najbiedniejszych i najbardziej upośledzonych warstw narodu, tak cecylianiści rozumieli konieczność przywrócenia odpowiedniej dla liturgii muzyki przez właściwie wykształcone i bytujące na dostatecznym poziomie zastępy muzyków kościelnych. 
Dlaczego wspominam w tym momencie cecylianistów i ich ruch odnowy? Dlatego, że niektóre ich postulaty są wciąż aktualne. Podniesienie poziomu muzyki liturgicznej w naszym kraju nadal jest zadaniem do wykonania, choć trzeba uczciwie przyznać, że sytuacja w tym względzie jest dużo lepsza niż w momencie pojawienia się cecylianizmu niemal półtora wieku wcześniej. W Polsce po roku 1989 (niektórzy nazywają go przełomowym) podjęte zostały różnorakie inicjatywy w celu sanacji muzyki kościelnej. Jedną z nich jest powstanie Stowarzyszenia Polskich Muzyków Kościelnych będącego (ale to daleka paralela i nie jestem przekonany, czy całkiem słuszna) pewnym odbiciem i przedłużeniem działającego w PRL w latach 1946-1949 i zlikwidowanego zresztą przez ówczesną władzę Zrzeszenia Księży Muzyków.

SPMK zostało powołane do życia oficjalnie w uroczystość św. św. Piotra i Pawła w 2001 roku w Opolu. Jest to data rejestracji Stowarzyszenia przez Sąd Rejonowy w Opolu - miejscowości, w której działało wówczas i nadal prężnie działa środowisko muzyków kościelnych.

Od pewnego czasu (nawet jeszcze przed 1989 rokiem) przy Komisji Episkopatu Polski ds. Nauki Katolickiej działała Sekcja Wykładowców Muzyki Kościelnej, odbywająca swe spotkania w cyklu dwuletnim. Właśnie podczas jednego z takich spotkań, w Konstancinie-Jeziornej (23-24 września 1999) idea powołania Stowarzyszenia Polskich Muzyków Kościelnych pojawiła się po raz pierwszy. Wobec faktu rozwiązania Podkomisji Episkopatu Polski ds. Muzyki uznano, że Sekcja Wykładowców traci rację istnienia. Przewodniczący Sekcji, ks. Ireneusz Pawlak, zaproponował przekształcenie Sekcji w Stowarzyszenie Polskich Muzyków Kościelnych.

Mimo że na tym zebraniu powołano tymczasowy Zarząd (ks. Ireneusz Pawlak, Andrzej Filaber, Antoni Reginek, Andrzej Zając, Piotr Paćkowski, Robert Tyrała, Remigiusz Pośpiech), zgromadzenia w Konstancinie-Jeziornej nie należy uznawać za I Zjazd SPMK. Nie był to bowiem jeszcze zjazd założycielski, raczej intencjonalny, a przede wszystkim wybrane gremium nie miało mocy prawnej do podejmowania uchwał. Naczelnym natomiast jego zadaniem było przygotowanie projektu statutu SPMK, który następnie miał być poddany ocenie przez członków-założycieli. Tak też się stało w dniu 20 września 2000 roku na zjeździe założycielskim w Trzebnicy, podczas którego dokonano formalnego prawnego umocowania $\mathrm{Za}$ rządu w niezmienionym składzie. Jednocześnie ten właśnie zjazd z punktu widzenia historycznego uznać należy za I Walne Zgromadzenie SPMK. Warto przy tym zauważyć, że wrześniowy termin spotkań członków SPMK, wówczas zaproponowany, przekształcił się w tradycję utrwaloną podczas następnych zjazdów.

Członkowie-założyciele SPMK to w większości ludzie w pewien sposób związani z Instytutem Muzykologii KUL, działający głównie na terenie Śląska i Małopolski. Jako że obrady odbywały się w Trzebnicy, Zarząd SPMK złożył oficjalną 
wizytę ordynariuszowi diecezji opolskiej, ks. abp. Alfonsowi Nossolowi, prosząc o akceptację Stowarzyszenia i wyrażenie zgody na uczynienie Opola jego siedzibą. Arcybiskup przychylił się do prośby Zarządu, pozostała więc do przebycia procedura rejestracji SPMK, szczęśliwie zakończona wpisem do KRS w Sądzie Rejonowym w Opolu, o czym wyżej wspomniałem. Kronika SPMK dokumentuje pierwszoplanową rolę i determinację członka Zarządu, Remigiusza Pośpiecha, w tym procesie.

Zaistnienie nowego stowarzyszenia, które wśród swoich zadań umieściło troskę o stan muzyki kościelnej, nie od razu przedarło się do świadomości muzyków kościelnych w całym kraju. W początkowych latach była to organizacja obejmująca swoją działalnością praktycznie południową połowę Polski. Prawdopodobnie najpoważniejszą tego stanu rzeczy przyczyną było silniejsze niż w przypadku podobnych ośrodków oddziaływanie Instytutu Muzykologii KUL na tę cześć kraju. Wraz z krzepnięciem i rozwojem SPMK sytuacja ta oczywiście zmieniła się na korzyść, tak że obecnie można śmiało stwierdzić, iż SPMK jest najpoważniejszą krajową organizacją skupiającą muzyków kościelnych.

Początkowo działania SPMK były z natury skromne. Przyjęła już się jednak zasada, że coroczne zjazdy będą kilkudniowe, w pierwszych latach dwu-, później trzydniowe. W trakcie każdego zjazdu jeden dzień poświęcony miał być sprawom organizacyjnym Stowarzyszenia, drugi natomiast przeznaczony został na dyskusję zogniskowaną wokół wcześniej ogłoszonej idei przewodniej. Owe dyskusje stopniowo przekształciły się w konferencje naukowe. Obok odczytów naukowych w trakcie zjazdów prezentowana była muzyka zarówno podczas codziennych liturgii, jak i specjalnie w tym celu organizowanych koncertach. Prezentacje artystyczne dokonywane były przy udziale już to miejscowych muzyków (organistów, chórów, zespołów instrumentalnych), już to muzyków zapraszanych „z zewnątrz”. Ukazuje to dbałość, z jaką od początku władze SPMK otaczały delikatny problem zrównoważenia proporcji między - nazwijmy to - skrzydłem artystycznym i naukowym wewnątrz Stowarzyszenia.

II Walne Zgromadzenie zwołano do Sikorza (diec. płocka) w dniach 13-14 września 2001 roku na zaproszenie księży diecezji płockiej, absolwentów IM KUL: Piotra Wiśniewskiego i Andrzeja Lelenia. Zjazdowi, który niekiedy w opracowaniach bywa określany I Walnym Zjazdem, przyświecało motto pamięci zmarłych muzyków kościelnych. Zjazd ten był istotny w historii SPMK, ponieważ w miejsce dotychczas funkcjonującego Zarządu (wciąż przecież tymczasowego) powołano skutecznie prawne władze Stowarzyszenia (to jest Zarząd, Komisję Rewizyjną i Komisję Kwalifikacyjna) na pełną kadencję 2001-2005.

W krótkim tekście nie ma miejsca na każdorazowe wymienianie pełnego składu tych gremiów - zainteresowanych można odesłać do pierwszego numeru biu- 
letynu. Odnotować wszak wypada, że przewodniczącym Zarządu (prezesem) został pomysłodawca przedsięwzięcia - ks. Ireneusz Pawlak.

III zjazd członków Stowarzyszenia Polskich Muzyków Kościelnych odbył się w Gródku n. Dunajcem (19-20 września 2002 roku). Wzięli w nim udział zaproszeni goście: bp Stefan Cichy - przewodniczący Komisji Kultu Bożego i Dyscypliny Sakramentów Konferencji Episkopatu Polski oraz Jan Boogaarts (Holandia), prezydent Consociatio Internationalis Musicae Sacrae. Obecność przewodniczącego Komisji Episkopatu Polski stanie się odtąd tradycją, w późniejszych latach jeszcze poszerzoną o osobę przewodniczącego Podkomisji Liturgicznej. W Gródku debatowano o stanie muzyki sakralnej w Polsce. Po raz pierwszy w dziejach SPMK, zgodnie z zapisami statutowymi, nadano tytuły honorowego członka SPMK ks. Kazimierzowi Pasionkowi, ks. Zbigniewowi Piaseckiemu, ks. Romualdowi Rakowi oraz Stefanowi Stuligroszowi.

Stowarzyszenie coraz śmielej wkraczało na teren nauki. Stawało się nie tylko organizatorem konferencji przy okazji dorocznych zjazdów, ale wykorzystując rocznicę 100-lecia opublikowania motu proprio Piusa X Inter pastoralis, współorganizowało wraz z Consotiatio Internationalis Musicae Sacrae i Instytutem Muzykologii KUL międzynarodowe sympozjum Historia i wspótczesność muzyki liturgicznej $w$ Polsce (Lublin 11-14 września 2003). To wydarzenie było jednocześnie IV zjazdem członkowskim.

W ten coraz bardziej wartko płynący nurt naukowy wpisuje się także zorganizowanie I Ogólnopolskiego Kongresu Muzyki Liturgicznej Musicam Sacram Promovere w połączeniu z V zjazdem SPMK (Kraków, 17-19 września 2004), a okazją do tego stała się 1400. rocznica śmierci św. Grzegorza Wielkiego oraz 25. rocznica ogłoszenia Instrukcji Episkopatu Polski O muzyce liturgicznej po Soborze Watykańskim II.

Zorganizowanie kongresu krakowskiego było wydarzeniem autentycznie znaczącym, jako że podobna inicjatywa w naszym kraju po raz ostatni doszła do skutku niemal pół wieku wcześniej, w Częstochowie w 1959 roku. Kongres stał się wyśmienitą okazją do wznowienia na szerokim forum (udział w nim wzięło ok. 400 osób) dyskusji nad stanem muzyki liturgicznej w Polsce.

VI Walne Zgromadzenie SPMK odbyło się w Opolu 12-13 września 2005 roku z okazji 10-lecia istnienia „Liturgia Sacra” - pisma naukowego, które odgrywa istotną rolę w kształtowaniu świadomości wartości i odrębności muzyki liturgicznej. Od tego momentu kolejne zjazdy odbywały się już w formule trzydniowej. Tematyka konferencji naukowej zogniskowana była wokół idei piękna obecnego w liturgii. Gościem specjalnym zjazdu był ceremoniarz papieski, ks. Konrad Krajewski, który podzielił się z uczestnikami tajnikami pracy zespołu ceremoniarzy papieskich. Jak widać, Zarząd SPMK dokładał dużo starań, by zjaz- 
dy członkowskie, będąc koniecznymi i naturalnymi spotkaniami towarzyskimi, poprzez konferencje naukowe i spotkania $\mathrm{z}$ wybitnymi osobistościami kultury kościelnej poszerzały także wiedzę oraz kształtowały postawy muzyków odpowiedzialnych za jej kształt bezpośrednio w parafiach.

Podczas tego zjazdu w miejsce dotychczasowych władz, których kadencja wygasała w 2005 roku, wybrano nowe władze. Przewodniczącym SPMK został ks. Antoni Reginek. Trzeba koniecznie dodać, że nowy Zarząd podjął decyzję o regularnym wydawaniu rocznika zatytułowanego „Biuletyn Stowarzyszenia Polskich Muzyków Kościelnych”, w którym publikowane miały być prace naukowe, recenzje, omówienia i sprawozdania - między innymi z działalności Stowarzyszenia. Założeniem było, iż każdy kolejny rocznik miał nosić inny tytuł - zgodny z leitmotivem zjazdu. Pierwszy numer z oczywistych względów miał charakter retrospektywny i ukazał się w 2006 roku. Kolejne ukazywały się w następnym roku po zjeździe.

Następny zjazd (VII) zorganizowano w Kokoszycach w archidiecezji katowickiej w dniach 12-14 września 2006 roku. Tematem wiodącym było kształcenie organistów na różnych poziomach i typach szkolnictwa w Polsce. Pokłosiem spotkania stał się drugi numer „Biuletynu” (pt. Ksztatcenie organistów wydany w 2007 roku). Gośćmi zjazdu byli bp Stefan Cichy oraz słowacki ksiądz, Rastislav Adamko, absolwent muzykologii KUL, pracownik Uniwersytetu Katolickiego w Rużomberku i członek Spiskiej Kapituły.

W trakcie zjazdu za dotychczasowy wysiłek podejmowany w trosce o muzykę liturgiczną w naszym kraju nadano ks. Ireneuszowi Pawlakowi tytuł Honorowego Prezesa. Jednocześnie Zarząd SPMK przyznał Dyplom Honorowy nieobecnemu w Kokoszycach ze względów zdrowotnych ks. Karolowi Mrowcowi za zaangażowanie w działalność Stowarzyszenia oraz znaczący wkład naukowy i pielęgnowanie muzyki liturgicznej.

$\mathrm{Na}$ miejsce kolejnego spotkania muzyków wybrano Koszalin. VIII zjazd odbywał się w dniach 11-13 września 2007 roku. Jego tematyka koncentrowała się wokół godności i posługi organisty w Kościele, czego materialnym śladem jest trzeci numer „Biuletynu” pt. Postuga organisty (wydany w 2008 roku). Ujawniono wówczas informację o przygotowywanym projekcie minimum programowego, mającego w zamyśle obowiązywać w diecezjalnych szkołach organistowskich. Wyrażono nadzieję, że zostanie on zatwierdzony przez Episkopat Polski. Celem dokumentu miało być wyrównanie poziomu kształcenia organistów w kraju i wzajemna uznawalność wystawianych dyplomów w diecezjach. Idea ta nie doczekała się jednak realizacji i właściwie należałoby ją podjąć od nowa, co powinno stać się jednym z zadań SPMK.

IX Walne Zgromadzenie SPMK zwołano do Lichenia. Obrady toczyły się w dniach 9-11 września 2008 roku. Generalnie były one dokończeniem debaty 
rozpoczętej rok wcześniej w Koszalinie. Tytuł zjazdu i w jego następstwie wydanego kolejnego numeru biuletynu, Muzyk kościelny (opublikowanego w 2009 roku), mówi sam za siebie. Spektrum zagadnień poszerzono o posługę liturgiczną muzyków, którzy są nie tylko organistami, aczkolwiek to właśnie oni stanowią grupę dominującą.

Przedłożone referaty były de facto informacjami o programach i warunkach kształcenia muzyków kościelnych na poziomie szkół diecezjalnych i wybranych szkół wyższych. Zaprezentowano także projekt regulaminu muzyków kościelnych wypracowany przez środowisko opolskie. Dokument ten zatytułowany Normy ogólne dla muzyków kościelnych postugujących $w$ diecezjach polskich przyjęto w trybie jednogłośnym przez Walne Zgromadzenie i postanowiono skierować go do Konferencji Episkopatu Polski z prośbą o zatwierdzenie.

Następny zjazd (X) odbył się ponownie na północy Polski, w Pelplinie - historycznej miejscowości imponującej monumentalną katedrą - w dniach 9-11 września 2009 roku. Tematyka, która zgromadziła członków i gości SPMK, dotyczyła muzyki instrumentalnej obecnej w liturgii. Temat zjazdu - Musica instrumentalis in Ecclesia: Species - Memoria - Perspectivae - dobrze oddaje obszar, na którym poruszali się zarówno prelegenci, jak i dyskutanci. Warto odnotować, że sformułowanie tematu zgromadzenia w języku łacińskim odtąd stanie się normą i znajdzie się na biuletynie SPMK jako jego coroczny tytuł.

Dyskusja nad referatami toczyła się wokół muzyki czysto organowej, także instrumentalnej, zasad użycia instrumentarium muzycznego podczas liturgii, koncertów i tym podobnych aspektów muzyczno-liturgicznych, również w perspektywie przyszłości. Nowym osiągnięciem w dotychczasowych dziejach Stowarzyszenia były podjęte dwa postanowienia. Pierwsze dotyczyło ogłoszenia przez SPMK dwóch otwartych konkursów na kompozycje: instrumentalną przeznaczoną do wykonywania w ramach liturgii oraz wokalną z przeznaczeniem na mszę świętą z udziałem dzieci. Sporządzenie projektów regulaminów powierzono odpowiednio Julianowi Gembalskiemu i Marcie Kierskiej-Witczak. Drugie postanowienie dotyczyło podjęcia pracy nad przygotowaniem projektu nowej instrukcji o muzyce liturgicznej wobec częściowego zdezaktualizowania się dotychczas obowiązującej Instrukcji Episkopatu Polski o muzyce liturgicznej po Soborze Watykańskim II z roku 1979. Koordynacji wysiłków w celu realizacji tego postanowienia podjął się ks. Andrzej Filaber. Jak się później okazało, praca nad tym wymagającym dokumentem trwała jeszcze kilka lat i wciąż nie zakończyła się sukcesem.

Podczas tego zjazdu przyjęto w poczet honorowych członków SPMK ks. Edwarda Hinza z Pelplina w uznaniu jego zasług dla rozwoju polskiej muzycznej kultury religijnej. Walne Zgromadzenie w Pelplinie dokonało także wybo- 
ru nowych władz wobec upływającej kadencji dotychczasowego Zarządu SPMK. Członkowie Stowarzyszenia powierzyli kierowanie Stowarzyszeniem na kolejną kadencję dotychczasowemu Zarządowi; prezesem ponownie został wybrany ks. Antoni Reginek.

XI zjazd SPMK odbywał się w Częstochowie na Jasnej Górze w dniach 8-10 września 2010 roku pod hasłem Musica liturgica. Taki też tytuł nosi szósty numer biuletynu SPMK, który ukazał się w 2011 roku. Zjazd zdominowały problematyka i perspektywy repertuaru śpiewów liturgicznych, zarówno istniejącego, jak i nowo tworzonego.

Zgromadzonym zaprezentowano przygotowane projekty regulaminów konkursów kompozytorskich na utwór instrumentalny i utwór wokalny na mszę świętą z udziałem dzieci jako wypełnienie pierwszego postanowienia zjazdu pelplińskiego. Omawiano także projekt nowej redakcji instrukcji o muzyce liturgicznej. Relator, ks. Filaber zaproponował utworzenie grup roboczych mających przygotować pierwszą redakcję poszczególnych jej działów.

Ksiądz Andrzej Draguła z Zielonej Góry w gościnnym wystąpieniu ukazał aspekty transmisji celebracji liturgicznych przez media, telewizję, radio, ich pozytywne strony, ale także zagrożenia dla duchowości, jakie owe transmisje niosą ze sobą. Po zakończeniu obrad uczestnicy mieli możliwość zwiedzenia biblioteki klasztornej - miejsca na ogół niedostępnego dla pielgrzymów.

Kolejny zjazd (XII) obradował w Warszawie (14-16 września 2011 roku). W całości wypełniła go tematyka przygotowywanej Instrukcji o muzyce liturgicznej. Ustalono wówczas terminy zgłaszania ewentualnych sugestii merytorycznych do powołanej przez Walne Zgromadzenie grupy redaktorów przygotowującej ostateczny tekst. Grupę tę tworzyli wówczas księża: Andrzej Filaber, Antoni Reginek i Andrzej Zając. Zainteresowanych szczegółami odesłać należy do siódmego numeru biuletynu Miscelanea (2012).

W dniach 11-13 września 2012 roku trzynasty doroczny zjazd SPMK odbył się w Białymstoku. Dominantą spotkania stał się śpiew liturgiczny wyrażony w temacie konferencji: Śpiewy liturgiczne w tradycji i wspótczesności - opracowania $i$ weryfikacje. Osią debaty stało się pytanie: przy pomocy jakich narzędzi można kwalifikować śpiew, zarówno już istniejący, jak i nowo powstający, jako liturgiczny? Ponadto wysłuchano komunikatu o postępie prac nad Instrukcją o muzyce liturgicznej oraz rozpoczęto dyskusję nad potrzebą nowej redakcji ogólnopolskiego śpiewnika kościelnego. Wszystkie materiały znajdują się w numerze w numerze 8 biuletynu De cantu sacro (2013).

XIV Walne Zgromadzenie odbyło się we Wrocławiu w dniach 10-12 września 2013 roku pod hasłem Dziedzictwo muzyki kościelnej, zgodnie z którym wystąpienia prelegentów podczas pierwszej sesji konferencji koncentrowały się wokół 
muzycznego środowiska wrocławskiego. Sesję drugą zdominowały sprawy, z którymi SPMK borykało się od dłuższego czasu: Instrukcja o muzyce liturgicznej oraz ogólnopolski śpiewnik liturgiczny. W kwestii Instrukcji zgromadzenie podjęło - jak się okazało, brzemienną do dziś - uchwałę o odesłaniu jej tekstu do konsultacji w Podkomisji ds. Muzyki Episkopatu Polski, mimo faktu nieobecności na zjeździe sprawozdawcy, ks. Michała Szulika. Kilka lat później okazało się, że była to decyzja podjęta bez odpowiedniego namysłu, gdyż większość (być może nawet wszyscy) sądzili, iż tekst po konsultacjach w Podkomisji wróci w przyszłości na forum walnego zgromadzenia w celu dokonania ostatecznych korekt.

Zjazd wrocławski był istotny dla Stowarzyszenia ze względu na konieczność wyboru nowych władz. Po dwóch kadencjach ks. Antoniego Reginka na stanowisku prezesa zastąpił go ks. Grzegorz Poźniak, który zaproponował skład Zarządu. Wybrano także pozostałe ciała kolegialne: Komisję Rewizyjną i Kwalifikacyjną na kadencję 2013-2017.

Od tego momentu sprawy Stowarzyszenia zaczęły wyraźnie nabierać dynamiki. Jeszcze we Wrocławiu nowy prezes przedstawił wizję działań Zarządu i określił priorytety, którymi stały się: absolutne przestrzeganie dyscypliny finansowej $\mathrm{w}$ powiązaniu z wymogami aktualnie obowiązującego prawa w zakresie księgowości i finansów, nadanie SPMK osobowości prawno-kanonicznej, całkowita przebudowa strony internetowej, nadanie jej profesjonalnego wyglądu i częste uaktualnianie, przekształcenie dotychczasowego „Biuletynu” w rocznik naukowy z przyznanymi punktami Ministerstwa Nauki i Szkolnictwa Wyższego. Zwrócił się do członków Stowarzyszenia o propozycję jego tytułu. W konsekwencji dziewiąty tom (2014) - a także kolejne - będą wydawane pod ujednoliconym tytułem „Musica Ecclesiastica”.

Jubileuszowy, XV Zjazd nowy Zarząd zwołał do Gniezna w dniach 23-25 września 2014 roku pod hasłem Omnis creatura laudet Creatorem suum. Zaproszenie wystosował ks. Dariusz Sobczak - członek SPMK i dyrektor Chóru Archikatedry Prymasowskiej, świętującego jubileusz 100-lecia działalności. Na wstępie ks. prezes zaprezentował zebranym stan realizacji działań, jakie w ciagu minionego roku podjął Zarząd, to jest starania o uzyskanie wpisania „Musica Ecclesiastica” na ministerialną listę czasopism punktowanych, modernizacja strony internetowej, wprowadzenie elektronicznego sekretariatu SPMK. Ogłosił także zasady przyznawania Patronatu Honorowego SPMK różnorakim inicjatywom społecznym w obszarze szeroko rozumianej promocji muzyki sakralnej oraz powołanie nowego gremium - Kapituły Medalu SPMK „Per musicam ad fidem”. Decyzją Kapituły pierwszy medal Stowarzyszenia Polskich Muzyków Kościelnych zostanie wręczony ks. Ireneuszowi Pawlakowi - założycielowi i ojcu SPMK, profesorowi i wychowawcy wielu jego obecnych członków. 
Ceremonii dokonano następnego dnia, po komunii świętej w czasie uroczystej mszy świętej sprawowanej w prastarej katedrze gnieźnieńskiej pod przewodnictwem prymasa Polski ks. abpa Wojciecha Polaka. Podczas liturgii zaprezentował się jubilat - Chór Prymasowski pod dyr. ks. Dariusza Sobczaka.

Wystąpienia naukowe w pierwszej sesji, dobrane w przemyślany sposób, dotykały problematyki powołania muzyka kościelnego do służby głoszenia Ewangelii przez muzykę i bycia świadkiem piękna. Druga sesja odbywała się - eksperymentalnie - rozdzielona na dwie sekcje tematyczne. Pierwsza kontynuowała rozważania muzykologiczne, w drugiej kontynuowano temat możliwości i potrzeby powstania śpiewnika ogólnopolskiego. Wobec zgłaszanych zastrzeżeń o braku możliwości wysłuchania wszystkich prelegentów zaniechano idei podziału sekcyjnego w przyszłości.

Wśród gości Zjazdu, obok tradycyjnie odwiedzającego to gremium bpa Stefana Cichego - przewodniczącego Podkomisji ds. Muzyki kościelnej - dołączył po raz pierwszy bp Adam Bałabuch, przewodniczący Komisji ds. Kultu Bożego i Dyscypliny Sakramentów. Obaj przedstawili postęp prac nadzorowanych komisji w zakresie muzyki. Gościem zjazdu był także red. Krzysztof Skowroński, prezes Stowarzyszenia Dziennikarzy Polskich, który podzielił się refleksją na temat organizacji i działania polskich mediów. Niestety z powodu choroby nie przybył zaproszony na zjazd Stefan Baier - rektor Hochschule für Katholische Kirchenmusik und Musikpädagogik w Regensburgu.

Ostatni z dotychczasowych zjazdów SPMK (XVI) odbył się w Legnicy i Krzeszowie w dniach 22-24 września 2015 roku. Ideą przewodnią stały się organy i muzyka organowa zawarte w łacińskim tytule zjazdu Laudate Dominum per organa benesonantia. Miejscem pobytowym była Legnica, natomiast konferencja naukowa pod tytułem Organy i muzyka organowa w kulturze Kościota odbyła się w klasztorze krzeszowskim. Temat organów niejako wywołany został obecnością szacownego instrumentu w bazylice krzeszowskiej. Wizyta w tym miejscu zaznaczona była uczestnictwem w liturgii mszalnej pod przewodnictwem ks. bpa Zbigniewa Kiernikowskiego, po której zwiedzono to historyczne miejsce. W ciągu trzech dni uczestnicy mieli możliwość wysłuchania nadzwyczajnie dużej liczby prezentacji muzycznych - tak w trakcie mszy świętej, jak i koncertów na kilku instrumentach w Legnicy i Krzeszowie.

Podczas spotkania planowano wręczenie II medalu SPMK ks. Janowi Chwałkowi. Niestety ze względu na jego stan zdrowia kameralna uroczystość miała miejsce tuż przez zjazdem. Wiedząc o niemożności przybycia zacnego gościa do Legnicy, delegacja Zarządu SPMK na czele z prezesem dokonała ceremonii wręczenia medalu w domu ks. Jana Chwałka nieopodal Sandomierza. Warto nadmienić, że ks. Chwałek nie jest członkiem SPMK, stąd jego uhonorowanie należy 
postrzegać jako wyjście z pewnymi inicjatywami poza ścisły krąg członków Stowarzyszenia.

Więcej informacji na temat XVI zjazdu znajdzie się w trzecim numerze „Musica Ecclesiastica”, to jest 11. numerze biuletynu SPMK (2016), który w trakcie pisania niniejszego tekstu był w druku. Rocznikowi od początku nadano profil pisma naukowego obejmującego problematykę szeroko rozumianej muzyki kościelnej. Jego łamy dostępne są dla wszystkich autorów, z pierwszeństwem jednak dla członków SPMK, zwłaszcza tych, którzy prezentują referaty na konferencjach naukowych organizowanych podczas walnego zgromadzenia.

Zawartość „Musica Ecclesiastica”, nad którą czuwa Rada Naukowa pod przewodnictwem ks. Grzegorza Poźniaka, podzielona została na kilka działów. W pierwszym publikowane są teksty referatów i komunikatów oraz artykuły naukowe związane z muzyką kościelną. Drugim działem jest przegląd wydawnictw zakresu muzyki kościelnej. W części trzeciej zamieszczane są sprawozdania z przedsięwzięć związanych z linią programową pisma, w tym przede wszystkim sprawozdania i kronika działalności Stowarzyszenia. Niniejszy artykuł powstał w dużej mierze właśnie na podstawie opublikowanych tekstów sprawozdań w kolejnych numerach rocznika. Jako ostatni dział funkcjonuje dodatek nutowy, będący zbiorem kompozycji rekomendowanych przez SPMK do wykonywania $\mathrm{w}$ trakcie liturgii i poza nią.

Trzeba koniecznie dodać, że staraniem Zarządu, a szczególnie prezesa, ks. Poźniaka, „Musica Ecclesiastica” ma obecnie przyznane 4 pkt. za publikacje naukowe, samo zaś pismo w drugiej połowie roku 2015 zostało umieszczone zostało na tak zwanej liście „B” wykazu pism naukowych $\mathrm{MNiSzW}$.

Tyle bardzo syntetycznego przeglądu wydarzeń, których uczestnikami byli członkowie SPMK w minionym 15-leciu. Ta retrospektywa poprowadzona została w optyce dorocznych zjazdów Stowarzyszenia, które jakkolwiek najbardziej widoczne w całej działalności, to jednak nie wyczerpują całości dokonań, zwłaszcza podejmowanych na corocznych spotkaniach przez Zarząd i pozostałe gremia SPMK.

Podczas każdorazowego zjazdu realizowane są żelazne punkty programu: centrum stanowi oczywiście liturgia mszalna sprawowana w drugim dniu zjazdu pod przewodnictwem najczęściej miejscowego biskupa, ewentualnie biskupa-gościa zjazdu. Każdego dnia sprawowana jest także liturgia godzin (w zależności od dnia: jutrznia bądź nieszpory), której przewodzi jeden z księży-członków SPMK. Istotnym punktem są konferencje, koncerty i prezentacje muzyczne, które zawsze spotykają się ze zrozumiałym zainteresowaniem i są przedmiotem późniejszych, nieformalnych dyskusji.

Harmonogram trzydniowych spotkań jest szczelnie wypełniony: od spraw administracyjno-organizacyjnych poprzez prezentację nowo przyjętych członków 
Stowarzyszenia, możliwość nabycia wydawnictw książkowych i nagrań płytowych, zwłaszcza jeśli ich autorami (wykonawcami) są koleżanki i koledzy. Zjazdy są doskonałą okazją do promocji ośrodków leżących z dala od głównych tras komunikacyjnych albo położonych w odległych zakątkach Polski. Stwarzają możliwość zwiedzenia takich miejsc, których na ogół nie ma się okazji zwiedzić. Starannie opracowane informatory zjazdowe stają się najpierw pomocą organizacyjną dla uczestników zjazdu, później dowodami uczestnictwa w wydarzeniach, na koniec zaś pamiątką po nich. Spotkania towarzyskie - wszak bez nich życie SPMK straciłoby dużo ze swego kolorytu - są okazją do ściślejszej integracji środowiska i zawiązywania bliższych znajomości.

$*$

Czy Stowarzyszenie Polskich Muzyków Kościelnych to jedna z wielu organizacji naukowo-artystycznych wśród działających w naszym kraju? I tak, i nie. Już w momencie jego powołania zarysowały się dwie przeciwstawne wizje tego, czym miałoby być SPMK. Według pierwszej dostęp do udziału w nim powinni mieć wszyscy muzycy kościelni, którzy tego zapragną, oczywiście przy zachowaniu praw i obowiązków z tego faktu wynikających. Druga koncepcja, nazwijmy tak, ostrożniejsza, postulowała narzucenie pewnych ograniczeń przy przyjmowaniu do Stowarzyszenia, upatrując w masowości konkretne zagrożenia dla tożsamości SPMK. Ostatecznie zwyciężyło drugie wyobrażenie SPMK, co znajduje do chwili obecnej odzwierciedlenie zarówno w liczebności członków, jak i jakości podejmowanych inicjatyw. Można powiedzieć, że SPMK jest sui generis organizacją elitarną. Kandydat bowiem musi legitymować się wyższym wykształceniem muzycznym bądź muzykologicznym (od stopnia magistra wzwyż) i czynną zawodową pracą w Kościele, a także dla Kościoła.

Jak trafnie ujął to ks. Ireneusz Pawlak w jednym z artykułów opublikowanych w „Biuletynie”, do Stowarzyszenia

kwalifikują się więc np. profesorowie muzyki w seminariach duchownych, organiści, dyrygenci chórów kościelnych, referenci kurialni do spraw muzyki kościelnej itp. Natomiast nie spełniają warunków uczestnictwa przygodni organiści, kompozytorzy tworzący dorywczo dzieła muzyki kościelnej, dyrygenci chórów świeckich, którzy raz po raz występują ze swoimi zespołami w kościołach itp.

Takie granice to przede wszystkim w wysokim stopniu gwarancja odpowiedniego poziomu merytorycznego członków SPMK z jednej strony, zaś z drugiej 
rękojmia odpowiedniej postawy, jakiej oczekuje się od ludzi pełniących służbę w Kościele. Rękojmi takiej udzielają zresztą dwaj członkowie SPMK, którzy wystawiają opinie o kandydacie na członka SPMK. Oczywiście litera prawa może zabijać, stąd w Statucie SPMK zawarto klauzulę wyjątkowości w przypadku ubiegania się o członkostwo SPMK osoby, która literalnie nie spełnia wszystkich wymogów, jednak z istotnych względów można ją przyjąć w poczet członków rzeczywistych bądź honorowych SPMK. O tym każdorazowo decydują Zarząd i Walne Zgromadzenie.

Statut SPMK daje także prawo wypowiadania się publicznie na temat muzyki kościelnej w różnych jej aspektach. W końcu członkowie Stowarzyszenia to kompetentni twórcy, naukowcy i praktycy, realizujący misję na co dzień. Takimi polami do wypowiedzi są opinie na temat powstających kompozycji aspirujących do miana liturgicznych, opinie na temat całokształtu repertuaru sakralnego, poziomu wykonawstwa, stanu instrumentarium muzycznego i innych. Takie opinie i ekspertyzy powinny trafiać do odpowiednich władz kościelnych w dobrze rozumianej trosce o właściwy poziom muzyki w naszych kościołach. SPMK nie ma natomiast żadnych instrumentów, których użycie mogłoby zapobiec propagacji repertuaru czy wykonawstwa niepożądanego z punktu widzenia czystości stylu kościelnego. Jest jedynie ciałem opiniującym i doradczym. I w tym między innymi obszarze manifestuje się jego, ograniczona zresztą, moc.

Już po ostatnim zjeździe Zarząd rozpoczął starania o nadanie SPMK osobowości prawno-kanonicznej. Rozmowy z upoważnionymi osobami ze strony Konferencji Episkopatu Polski są od pewnego czasu prowadzone. Jest to skomplikowany proces, ponieważ zaistniała konieczność wprowadzenia zmian do dotychczas obowiązującego Statutu Stowarzyszenia, uwzględniających wymogi prawa zarówno państwowego, jak i kościelnego. Zarząd z tego powodu musiał wskazać asystenta kościelnego, którym został ks. Joachim Waloszek. Okazało się także, że Instrukcja o muzyce sakralnej nie zostanie poddana ostatecznej redakcji przez SPMK - czego spodziewali się wszyscy na zjeździe we Wrocławiu - lecz prawdopodobnie będzie zatwierdzona przez Komisję Episkopatu Polski. Do czasu pisania tego tekstu kwestia ta nie została jeszcze rozstrzygnięta.

Wszystkie jednak, najbardziej nawet szlachetne i dobrze zorganizowane przedsięwzięcia byłyby do pewnego stopnia sztuczne i schematyczne, gdyby nie działał w nich ożywczy duch. Pozwolę sobie zatem ponownie przytoczyć wypowiedź ks. Pawlaka:

Zasadniczym bowiem inspiratorem pozostaje Duch, który ogarnia wszystko, nadaje inny wymiar ludzkim wysiłkom, tylko on ożywia i „tchnie, kędy chce”, podsuwając różnorakie pomysły na miarę potrzeb i możliwości. Tak 
rozumiana rola SPMK może stanowić wielką szansę dla rozwoju muzycznej kultury Kościoła nie tylko w Polsce, ale także na terenie jednoczącej się Europy ${ }^{1}$.

\section{Streszczenie}

\section{Stowarzyszenie Polskich Muzyków Kościelnych. Retrospektywa}

Artykuł jest syntetycznym przeglądem i podsumowaniem działalności Stowarzyszenia Polskich Muzyków Kościelnych od momentu jego powstania w 2001 roku do XVI Zjazdu we wrześniu 2015 włącznie.

\section{Summary}

\section{Association of Polish Church Musicians. Retrospective}

The article is a brief review and summary of the activities of the Association of Polish Church Musicians since its establishment in 2001 until the 16th congress in September 2015.

Stowa kluczowe Stowarzyszenie Polskich Muzyków Kościelnych, koncert, konferencja, kongres, muzyka liturgiczna

Key words Association of Polish Church Musicians, concert, conference, congress, liturgical music

\section{Bibliografia}

Garnczarski S., Sprawozdanie ze zjazdu Stowarzyszenia Polskich Muzyków Kościelnych, [w:] Postuga organisty („Biuletyn SPMK” 3), Opole-Lublin 2008, s. 7-9.

Garnczarski S., Stowarzyszenie Polskich Muzyków Kościelnych (stan z września 2008 roku), [w:] Muzyk kościelny („Biuletyn SPMK” 4), Opole-Lublin 2009, s. 7-10.

1 I. Pawlak, Stowarzyszenie Polskich Muzyków Kościelnych szansą dla rozwoju muzycznej kultury Kościota, [w:] Stowarzyszenie Polskich Muzyków Kościelnych w latach 2001-2005 („Biuletyn SPMK” 1), Opole-Lublin 2006, s. 23. 
Garnczarski S., Sprawozdanie ze zjazdu Stowarzyszenia Polskich Muzyków Kościelnych (Pelplin - 9-11 IX 2009 r.), [w:] Musica instrumentalis, („Biuletyn SPMK” 5), OpoleLublin 2010, s. 13-16.

Garnczarski S., Sprawozdanie ze zjazdu Stowarzyszenia Polskich Muzyków Kościelnych (Jasna Góra - 8-10 IX 2010 r.), [w:] Musica liturgica („Biuletyn SPMK” 6), Opole-Lublin 2011, s. 15-18.

Garnczarski S., Sprawozdanie ze zjazdu Stowarzyszenia Polskich Muzyków Kościelnych (Warszawa 14-16 IX 2011 r.), [w:] Miscellanea („Biuletyn SPMK” 7), Opole-Lublin 2012, s. 11-13.

Garnczarski S., Sprawozdanie ze zjazdu Stowarzyszenia Polskich Muzyków Kościelnych (Biatystok - 11-13 IX 2012 r.), [w:] De cantu sacro („Biuletyn SPMK” 8), Opole-Lublin 2013, s. 9-14.

Garnczarski S., Sprawozdanie ze zjazdu Stowarzyszenia Polskich Muzyków Kościelnych, „Musica Ecclesiastica” 9 (2014), s. 95-98.

Nowak D., Sprawozdanie z XV Zjazdu Stowarzyszenia Polskich Muzyków Kościelnych-Gniezno 23-25 września 2014 r., „Musica Ecclesiastica” 10 (2015), s. 157-160.

Pawlak I., Stowarzyszenie Polskich Muzyków Kościelnych szansą dla rozwoju muzycznej kultury Kościota, [w:] Stowarzyszenie Polskich Muzyków Kościelnych w latach 2001-2005 („Biuletyn SPMK” 1), Opole-Lublin 2006, s. 19-23.

Poźniak G., Historia Stowarzyszenia Polskich Muzyków Kościelnych, [w:] Stowarzyszenie Polskich Muzyków Kościelnych w latach 2001-2005 („Biuletyn SPMK” 1), Opole-Lublin 2006, s. 33-42.

Reginek A., Sprawozdanie ze zjazdu Stowarzyszenia Polskich Muzyków Kościelnych, [w:] Ksztatcenie organistów („Biuletyn SPMK” 2), Opole-Lublin 2007, s. 7-9. 